\title{
Ethanolic Extract of Citrus reticulata Peel Inhibits the Migration of WiDr Colon Cancer Cells
}

\author{
Yoni Astuti ${ }^{1}$, Aulia Primasari ${ }^{2}$ \\ ${ }^{1}$ Biochemistry Department, School of Medical, Faculty of Medical and Health Sciences, \\ Universitas Muhammadiyah Yogyakarta \\ ${ }^{2}$ School of Medical, Faculty of Medical and Health Sciences, Universitas Muhammadiyah Yogyakarta
}

\begin{abstract}
Colorectal cancer is third rank on the cancer cases in Indonesia. To cure the cancer needs big cost and lot of effort. On the other side, the side effect of medicine or chemotherapy on patient need to reduce. Cancer cell spread to other tissue based on its migration and invasion ability. Citrus reticulata peel contains flavonoid such as Tangeretin and Nobiletin, both of this compounds have anticancer activity. The aims of this study is to reveals the potency of ethanol extract of Citrus reticulata peel on the inhibition of migration on WiDr colon cancer cells. The toxicity of ethanol extract of Citurs reticulata peel on WiDr colon cancer line was measured using 3-(4,5-dimethyltiazol-2-il)-2,5-diphenyltrazolium bromide (MTT) assay and investigate the cell migration was using scratch wound healing assay. The ethanol extract of Citrus reticulata peel showed the value of inhibitory concentration $50\left(\mathrm{IC}_{50}\right)$ was $184.5 \mu \mathrm{g} /$ $\mathrm{mL}$, this result categorize as moderate cytotoxic. Meanwhile the migration assay showed that the deceleration of migration occurred on $0.5 \mathrm{IC}_{50}, 0.33 \mathrm{IC}_{50}$ and $0.25 \mathrm{IC}_{50}$ during $24 \mathrm{~h}$ and $36 \mathrm{~h}$ incubation, event thought there were not significant different $(p>0.05)$. The ethanol extract of Citrus reticulata peel has a potential migration inhibition on WiDr cell line.
\end{abstract}

Keywords: Citrus reticulata, WiDr cell line, migration

\section{INTRODUCTION}

Cancer is one of the causes of death in the whole world. The evidence of cancer around $56.8 \%$ and the death cause of cancer (64.9\%) grow on the develop country in 2012 and was predicted increasing 19.3 new cases per year in 2025 (WHO, 2013). Colorectum cancer is ranked third after breast cancer and lung cancer (WHO, 2013). The highest mortality of colorectum cancer at Central and East Europe (20.3 per 100,000 for male and 11.7 per 100,000 for female). Colorectum cancer in Indonesia has a third position as 12.8 per 100,000 for adult community and has $9,5 \%$ mortality of total cancer evidence (IARC, 2012).
Most of colorectal patient come to the hospital with worse condition due to unknown early signs of cancer or ignored this sign event. (Ministry of Health of RI, 2017). Cancer started from uncontrolled growth cell. Repair DNA failed to work and then induced mutation on genome of soma cell. Colorectal cancer was malignancies on colon tissue, especially on part of colon and rectum. The malignancy is begun from proliferation and migration of cell, invasion cell to other tissue such as blood and to other organ and growing fast after

Submitted: December 11, 2019

Revised: April 30, 2020

Accepted: May 15, 2020

*Corresponding author: yoni_astuti@yahoo.co.id 
constructs new vessel to fulfill nutrient demand for their metabolism.

The inhibition of cancer cell migration is very important effort to prevent invasion to other tissue. There were many ways to cure colon cancer such as chemotherapy, take medicine, and surgery. In addition, the side effect during cancer therapy still a major problem. The exploration of adjuvant medicine to reduce the side effect is necessary to do the most important effect to prevent the malignancies of cell and invasion cancer cell to other tissue. Many plants used to as basic material to prevent from many diseases, including cancer. For example, Citrus reticulata peel has been reported contain of tangeritin and nobelitin, member of flavonoids (Shu-Fen, et al., 2004 and Morley, 2007).

Tangeritin was able to inhibit HL-60 Leukemia cancer cell (Hirano, et al., 1995) and to induce cell-cycle G1 arrest. Tangeritin was reported has the lowest inhibitory concentration $50\left(\mathrm{IC}_{50}\right)$ than other flavonoids on COLO 205 colon cancer cell (Pan, et al., 2002). Nobelitin has activity to suppress the production of MMP1.9 on HT1080 human fibrosarcoma cancel cell line (Sato, et al., 2002), inhibit activity of MCF breast cancer cell line and NCI-H460 lung cancer cell line, basal skin carcinoma (Wu, et al., 2015).

Tahsin, et al., 2017 showed that the extract contain of scoparone, xanthyletin, lupeol, $\beta$-amyrin, stigmasterol, $\beta$-sitosterol and palmitic acid. Ethanolic extract of Citrus reticulata was reported has ability to suppress the expression of $\mathrm{N}-$ Ras and c-Myc on liver cancer on Rat (Nugroho and Putri, 2008). Tangeritin in Citrus reticulata showed a proliferation inhibition on MCF-7 and MDA-MB435 breast cancer cell lines, also HT-29 colon cancer cell line for 4 days investigation and $\mathrm{G}$ arrest phase on 24, 48, dan $72 \mathrm{~h}$ (Morley, et al., 2007). There has been no evidence about tangeritin or nobelin in its ability to inhibit the migration of cancer cells. This research is conducted to explore the potential of ethanolic extract of Citrus reticulata peel as inhibitor in migration of WiDr cell line as a model of human colon cancer cell.

\section{MATERIALS AND METHODS}

\section{Extraction of Citrus reticulata Using Maceration Methods}

Sixty grams ( $60 \mathrm{~g})$ of Citrus reticulata peel powder was put in three of $1000 \mathrm{~mL}$ Erlenmeyer (20 g each) extracted using $200 \mathrm{~mL} \mathrm{95 \%} \mathrm{ethanol}$ solvent. Samples were extracted for $24 \mathrm{~h}$ and shaken for $3 \mathrm{~h}$ at room temperature. The dissolved fraction in ethanol is separated, put into a flask and the pulp obtained was macerated using same solvent. This extraction was carried out three times. Second repetition and third, the volume of immersion solvent is $150 \mathrm{~mL}$. The filtrate obtained was concentrated with a vacuum rotary evaporator at a $60^{\circ} \mathrm{C}$ and stopped when the extract was thick enough, marked by stopping the solvent dropping on the round bottom flask. The thick extract was stored at a temperature of less than $20^{\circ} \mathrm{C}$ to prevent damaged.

\section{WiDr Cancer Colon Maintenance}

WiDr cancer colon from Cancer Chemoprevention Research Center, Faculty of Pharmacy, Universitas Gadjah Mada were maintenance in RMPI, enriched with FBS, fungizone, Streptomycin/penicillin. The cell growth until $80 \%$ confluence for treatment. Trypsin and EDTA was used to detach the cell.

\section{Cytotoxic Test using 3-(4,5-dimethyltiazol- 2-il)-2,5-diphenyltrazolium bromide (MTT) assay}

The principle of the 3-(4,5-dimethyltiazol2-il)-2,5-diphenyltrazolium bromide (MTT) method is the reduction of yellow tetrazolium MTT salt to be purple formazan crystals by the succinate dehydrogenase enzyme due to cellular metabolic activity by $\mathrm{NAD}(\mathrm{P}) \mathrm{H}$-dependent cellular enzyme oxidoreductase in the cell respiration pathway in the mitochondria (Berridge, et al., 2005). Addition of stopper reagent (which is detergent) will dissolve this colored crystal then absorbed using an Enzyme- 
linked immunosorbent assay (ELISA) reader. The intensity of the purple color is proportional to the number of living cells. If the intensity of the purple color is greater, it means that the number of living cells is increasing.

The sample to be used in the cytotoxic test consisted of nine treatment groups. First group was WiDr cells as negative controls that were not given any treatment and only allowed to grow in the growth media. Second group was WiDr cells as positive controls given doxorubicin as a standard cancer drug with doses of $7.5 \mu \mathrm{g} / \mathrm{mL}, 15 \mu \mathrm{g} / \mathrm{mL}$, and $20 \mu \mathrm{g} / \mathrm{mL}$. The $3^{\text {rd }}, 4^{\text {th }}, 5^{\text {th }}, 6^{\text {th }}$ and $7^{\text {th }}$ group were WiDr cells that were given ethanol extracts of Citrus reticulata peel with dosages $10 \mu \mathrm{g} / \mathrm{mL}, 40 \mu \mathrm{g} / \mathrm{mL}$, $80 \mu \mathrm{g} / \mathrm{mL}, 100 \mu \mathrm{g} / \mathrm{mL}$. The positive and negative control groups were repeated three times in each treatment group. Meanwhile, the cell groups that were given ethanol extracts of Citrus reticulata peel were repeated five times for each treatment group.

\section{Migration Assay using Scratch Wound Healing Assay}

Aproximately $5 \times 10^{4}$ of WiDr cell line were seeded on the six well plate. This cell were devide into six treatment groups with negative control (cell with media only) and positive control (using doxorubicin). Treatment doses were $1 / 2 \mathrm{IC}_{50}, 1 / 3$ $\mathrm{IC}_{50}, 1 / 4 \mathrm{IC}_{50}, 1 / 8 \mathrm{IC}_{50}$ of ethanol extract of Citrus reticulata peel. After cell attached and spread then growing around $80 \%$ confluent, make a scratch using sterile yellow tip. A scratch will removed the cell, and became a discrete area so each edge cell can migrate to the empty area. Then add $5 \mathrm{~mL}$ treatment solution as well. On 0,12 and $24 \mathrm{~h}$ took a picture to every treatment and analyze using image J software. The migration test was repeated three times for each treatment.

\section{Data Analysis}

Data was represented as mean $\pm \mathrm{SD}$, the significant value continued with LSD. Data analyzed using SPSS program. Ethical clearance for this research was issued with number 643/EPFKIK-UMY/XII/2017.

\section{RESULTS}

The average of WiDr colon cancer cell viability showed depending of dose on ethanol extract Citrus reticulata as shown in Table 1. The increasing of dose was followed by the decreasing of WiDr colon cancer cell viability.

Table 1 . The average of viability WiDr cell line on depending of dose.

\begin{tabular}{cc}
\hline $\begin{array}{c}\text { Dose of Ethanol Extract of } \\
\text { Citrus reticulata }(\boldsymbol{\mu g} / \mathbf{m L})\end{array}$ & $\begin{array}{c}\text { WiDr Colon Cancer Cell } \\
\text { Viability (\%) }\end{array}$ \\
\hline 10 & $90.7 \pm 0.034$ \\
40 & $72.7 \pm 0.121$ \\
80 & $69.2 \pm 0.07$ \\
100 & $63.6 \pm 0.05$ \\
240 & $9.2 \pm 0.023$ \\
\hline
\end{tabular}

The adding 30, 60 and $140 \mu \mathrm{g} / \mathrm{mL}$ of dose were followed by decreasing as $22 \% ; 3 \% ; 8.6 \%$ and $53.8 \%$ of WiDr colon cancer cell line viability. Figure 1 showed the $\mathrm{IC}_{50}$ of ethanol extract of Citrus reticulata peel was $184.5 \mu \mathrm{g} / \mathrm{mL}$.

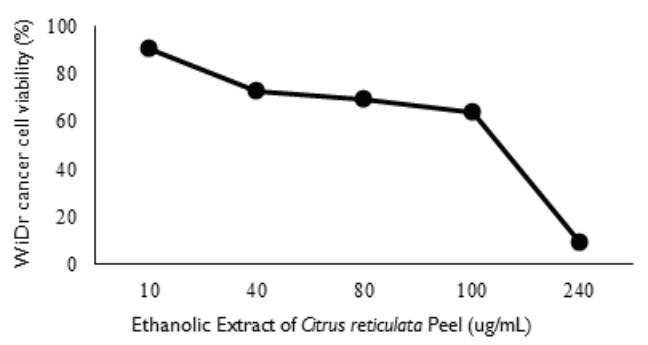

Figure 1. Percentage of WiDr cell line viability depending dose of Citrus reticulata peel ethanlolic extract. 
Meanwhile as a positive control was doxorubicin on some doses experiment as shown in Table 2. The $\mathrm{IC}_{50}$ of doxorubicin was $7.5 \mu \mathrm{g} / \mathrm{mL}$.

Table 2 The result of doxorubicin treatment on WiDr colon cancer cell viability.

\begin{tabular}{cc}
\hline $\begin{array}{c}\text { Doxorubicin } \\
(\mu \mathrm{g} / \mathrm{mL})\end{array}$ & $\begin{array}{c}\text { Widr Colon Cancer } \\
\text { Cell Viability }(\%)\end{array}$ \\
\hline 7.5 & $52.74 \pm 0.06$ \\
15 & $47.95 \pm 0.04$ \\
20 & $16.09 \pm 0.02$ \\
\hline
\end{tabular}

The migration WiDr colon Cancer cell per $12 \mathrm{~h}$ shown on Figure 2. Figure 2 showed that all groups have decreasing on their migration area depending of time. The anova analyzed showed that there were difference between all groups. Event it's not significance $(p>0.05)$.

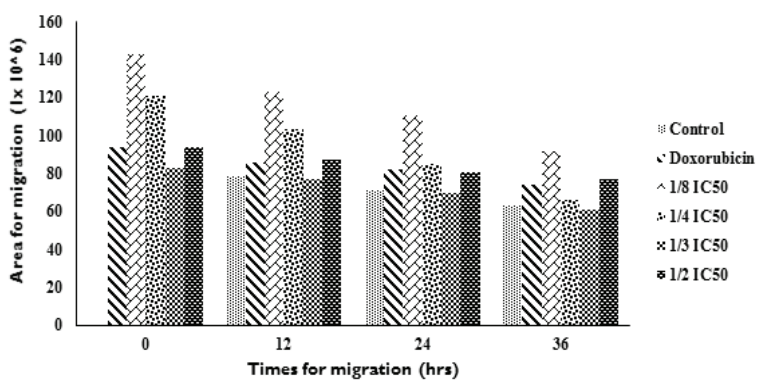

Figure 2. The inhibition of migration from Citrus reticulata peel extract on WiDr Colon Cancer Cell using scratch wound healing assay. WiDr cell were seeded in six well plate after confluence then scratch with blue tip and wash with PBS. The cell then treated with doxorubicin (positive control), $1 / 8 \mathrm{IC} \mathrm{C}_{50}, 1 / 4 \mathrm{IC} \mathrm{C}_{50}, 1 / 3 \mathrm{IC} \mathrm{C}_{50}$ and $1 / 2 \mathrm{IC}_{50}$ of ethanol extract of Citrus reticulata. This assay was measured for 12,24 and $36 \mathrm{~h}$.

The percentage WiDr colon cancer cell area migration as shown on Table 3 . On the $12 \mathrm{~h}$ the smallest area migration on the $1 / 2 \mathrm{IC}_{50}$ and the largest area migration on $1 / 4 \mathrm{IC}_{50}$. On the $24 \mathrm{~h}$ the smallest area migration on doxorubicin and the largest on the $1 / 4 \mathrm{IC}_{50}$. On the $36 \mathrm{~h}$, the smallest area migration on the $1 / 2 \mathrm{IC}_{50}$ and the largest area migration on the $1 / 4 \mathrm{IC}_{50}$.
Table 3. showed the interval per $12 \mathrm{~h}$ that control group have stabile acceleration of migration, almost similar with the $1 / 3 \quad \mathrm{IC}_{50}$ group but doxorubicin have twice acceleration of migration (from 4.3 to 8.3). The decreasing migration on $1 / 2$ $\mathrm{IC}_{50}$ (from 6.9 to 4 ).

Table 3. Persentage of WiDr colon cancer cell area migration.

\begin{tabular}{ccccccc}
\hline $\begin{array}{c}\text { Migration } \\
\text { Time (hour) }\end{array}$ & $\begin{array}{c}\text { Negative } \\
\text { Control }\end{array}$ & $\begin{array}{c}\text { Doxorubicin } \\
\text { (\%) }\end{array}$ & & \multicolumn{4}{c}{ Citrus reticulata Peel Extract (\%) } \\
\cline { 5 - 7 } & $\mathbf{( \% )}$ & & $\mathbf{I C}_{50}$ & $\mathbf{I C}_{50}$ & $\mathbf{I C}_{50}$ & $\mathbf{I C}_{50}$ \\
\hline 12 & $\mathrm{II} .6$ & 8.4 & 13.9 & 15.0 & 6.7 & 7.0 \\
24 & 19.9 & 12.7 & 22.4 & 29.8 & 16.0 & 13.9 \\
36 & 28.8 & 21.0 & 36.1 & 45.3 & 25.9 & 17.9 \\
\hline
\end{tabular}

Table 4. Interval percentage of WiDr colon cancer cell area migration.

\begin{tabular}{|c|c|c|c|c|c|c|}
\hline \multirow{2}{*}{$\begin{array}{l}\text { Interval on the } \\
\text { Migration } \\
\text { Time (hour) }\end{array}$} & \multirow{2}{*}{$\begin{array}{l}\text { Control } \\
(\%)\end{array}$} & \multirow{2}{*}{$\begin{array}{c}\text { Doxorubicin } \\
\text { (\%) }\end{array}$} & \multicolumn{4}{|c|}{ Citrus reticulata Peel Extract (\%) } \\
\hline & & & $\begin{array}{c}\mathrm{I} / 8 \\
\mathrm{IC} \mathrm{C}_{50}\end{array}$ & $\begin{array}{l}\mathrm{I} / 4 \\
\mathrm{IC} \mathrm{C}_{50}\end{array}$ & $\begin{array}{l}\mathrm{I} / 3 \\
\mathrm{IC} \mathrm{C}_{50}\end{array}$ & $\begin{array}{c}I / 2 \\
I C_{50}\end{array}$ \\
\hline $12-24$ & 8.3 & 4.3 & 8.5 & 14.8 & 9.3 & 6.9 \\
\hline $24-36$ & 8.9 & 8.3 & 13.7 & 15.5 & 9.9 & 4.0 \\
\hline
\end{tabular}

\section{DISCUSSION}

This study reveal that extract ethanol Citrus reticulata peel have antimigration effect, as compared with doxorubicin. The $1 / 2 \mathrm{IC}_{50}$ of extract ethanol Citrus reticulata have the largest effect on antimigration of WiDr colon cancer cell than others dose, as shown had the lowest area tomigrate. This result in line with Celano, et al. (2015) that reported the extract caused a reduction of cell migration, associated with decreased activity of the metalloproteinase MMP-2. These findings show that the flavonoid fraction of Citrus reticulata juice exerts in vitro antiproliferative effects on ATC cells (Human Tyroid cancer cell line), associated with a reduction of migration. This result also in line with Ajikumaran S Nair, et al. (2018) reported that Citrus reticulata peel water extract at $25,50 \mu \mathrm{g} /$ $\mathrm{mL}$ showed $100 \%$ cell death in DLA cells (Dalton's Lymphoma Acites) also had antitumor on mice. 
Meanwhile Tahsin, et al. (2017) showed that the extract of n-hexane (Hex) of Citrus reticulata Blanco bark, contain of scoparone, xanthyletin, lupeol, $\beta$-amyrin, stigmasterol, $\beta$-sitosterol and palmitic acid, had $\mathrm{IC}_{50}$ values as $53.0 ; 52.4$ and $49.1 \mu \mathrm{g} / \mathrm{mL}$ against the cancer cell lines A54 (human lung adenocarcinoma cell line), MCF7 (human breast adenocarcinoma cell line) and PC3 (human Caucasian prostate adenocarcinoma. In line with Kim, et al. (2005) reported that Citrus reticulata had an apoptosis effect on Human Gastric Cancer Cells SNU668 by the high expression on Bax, caspase 3 and low expression of $\mathrm{BCl} 2$ on dose and time dependent manner. The inhibition of migration, invasion and proliferation liver cancer cell via down regulation of MMP-2/9, N-cadherin, and vimentin induced by combination between Citrus reticulate peel and black tea (Wen, et al., 2019). Similar result showed by Chang, et al. (2015), that Citrus reticulate has inhibitory effect on ovarian cancer metastasis, also inhibit TGF- $\beta 1$-induced EMT through the canonical TGF- $\beta 1$-SMAD-Snail/Slug axis.

As known that Citrus reticulata contains of some flavonoids such as tangeritin, nobilin (Morley, 2007) also narirutin, hesperidin (Tumbas, et al., 2010). Citrus reticulata have many bioactivity i.e., as anticancer (Garcia and Castillo, 2008; Wu, et al., 2015), antibacteria activity, (Hamdan et al., 2016) and antiinfamatory (Boughendjioua and Boughendjioua, 2017). Tangeritin and nobelitin in Citrus reticulata can up-regulate p53 expression. Flavonoids can act as all three types of agent, as to inhibit enzymes involved in cell activation. Attempts to control cancer involve a variety of means, including the use of suppressing, blocking, and transforming agents. Suppressing agents prevent the formation of new cancers from procarcinogens, and blocking agents prevent carcinogenic compounds from reaching critical initiation sites, while transformation agents act to facilitate the metabolism of carcinogenic components into less toxic materials or prevent their biological actions (Gracia and Castilo, 2008). Event Tangeritin and Nobelitin already proved have a role on suppress the apoptosis cancer cell also as antiaangiogenetic on CAM (Chrisnanto, et al., 2008).

This research is pre elementary research with the small repetition (five repetition) on each group. The following research should conduct to prove the sufficient of dose that controlled the migration of cell cancer consider preventing the cancer expression, especially for the people who has high risk to express cancer. Either to use the primer human colon cancer cell to explore the real result for human that has high risk of colon cancer.

\section{CONCLUSION}

The present research is pre eleminary for antimigration inhibition of ethanolic extract Citrus reticulata. The concentration of ethanolic extract Citrus reticulata on $1 / 2 \mathrm{IC}_{50}$ able to inhibits the migration of WiDr Colon Cancer Cell. Hopefully, the future research will reveals about the mechanism and pathway of this activity.

\section{REFERENCES}

Ajikumaran, S.N., Rajani Kurup, S.R., Akhila, S.N. and Sabulal, B., 2018. Citrus peels prevent cancer, Phytomedicine, 50, 231-231.

Boughendjioua, H. and Boughendjioua, Z., 2017, Chemical Composition and Biological Activity of Essential Oil of Mandarin (Citrus reticulata) Cultivated in Algeria, Int. Journal Pharmacy Sciences. Reviews, 40, 179-184.

Celano, M., Maggisano, V., Francesca De Rose, R., Bulotta, S., Maiuolo, J., Navarra, M., et al., 2015, Flavonoid Fraction of Citrus Reticulata Juice Reduces Proliferation and Migration of Anaplastic Thyroid Carcinoma Cells, Nutrition and Cancer, 67(7), 1183-1190.

Chang, L., Jia, S., Fu, Y., Zhou, T., Cao, J., et al., 2015, Ougan (Citrus reticulate cv. Suavissima) flavedo extract suppresses cancer motility by interfering with epithelial-to-mesenchymal 
transition in SKOV3 cells, Chinese Medicine, 10(14), 1-10.

Chrisnanto, E., Rosa, A., Putri, D.D.P., Sahid, M.N.A., Setyaningtias, D., Jenie, R.I. and Meiyanto, E., 2008. Antiangiogenic Effect of Ethanol Extract of Citrus Reticulata Peel In The Chorio Allantoic Membrane (CAM) Induced by bFGF, Proceeding Molecular Targeted Therapy Symposium 2008. pp: 57-66.

García, O.B. and Castillo, J., 2008, Update on uses and properties of citrus flavonoids: new findings in anticancer, cardiovascular, and anti-inflammatory activity, Journal Agriculture Food Chemical, 13; 56(15), 6185-6205.

Hamdan, D.I., Mohamed, M.E. and El-Shazly, A.M., 2016. Citrus reticulata Blanco cv. Santra leaf and fruit peel: A common waste products, volatile oils composition and biological activities, Journal of Medical Plants Research, 10(30), 457-467.

Hirano, T., Abe, K., Gotoh, M. and Oka, K. 1995, Citrus flavone tangeretin inhibits leukaemic HL-60 cell growth partially through induction of apoptosis with less cytotoxicity on normal lymphocytes, British Jounal of Cancer, 72(6), 1380-1388.

International Agency for Research on Cancer (IARC)/ WHO. (2012), GLOBOCAN 2012. Estimated cancer incidence, mortality, and prevalence world wide in 2012.

Kim, M.J., Park, H.J., Hong, MK., Kim, M.S., Leem, K.H, et.al 2005, Citrus reticulata Blanco Induces Apoptosis in Human Gastric Cancer Cells SNU-668, Journal Nutrition and Cancer, 51, 7882.

Ministry of Health of the Republic of Indonesia, 2017, National Guidelines for Services Colorectal Cancer Medicine. National Cancer Management Committee, Jakarta.

Morley, P., Ferguson, J. and Koropatnick, J., 2007, Tangeretin and nobiletin induce $\mathrm{G} 1$ cell cycle arrest but not apoptosis in human breast and kolon cancer cells, Cancer Letters, 251(1),
168-178.

Nugroho, P.A., Putri, D.A., Darma, A.P., Riyanto, S. and Meiyanto, E., 2008, Searching for the mechanism of suppression of $\mathrm{N}$-Ras expression of Citrus reticulate Ethanolic Extract (Citrus reticulate) as a Chemopreventive Agent for Molecular Docking on C-SRC and CYP1A2 Target Proteins, Proceeding, XVI Scientific Congress of the Indonesian Pharmaceutical Science Association, 184-192.

Pan, M.H., Chen, W.J., Lin-Shiau, S.Y., Ho, C.T and Lin, J.K., 2002, Tangeretin induces cell-cycle G1 arrest through inhibiting cyclin-dependent kinases 2 and 4 activities as well as elevating Cdk inhibitors p21 and p27 in human colorectal carcinoma cells, Carcinogenesis, 23(10), 1677 1684.

Sato, T., Koike, L. and Miyata, Y., 2002, Inhibition of activator protein-1 binding activity and phosphatidylinositol 3-kinase pathway by nobiletin, a polymethoxy flavonoid, results in augmentation of tissue inhibitor of metalloproteinases-1 production and suppression of production of matrix metalloproteinases-1 and -9 in human fibrosarcoma HT-1080 cells, American Association for Cancer Research, 62, 1025-1029.

Shu-Fen, Z., Bing-lun, M.A., Da-wei, Z. and Qianhuan, D., 2004, Qualitative Analysis of Polymethoxylated Flavones in Citrus Peels by LC-AP$\mathrm{Cl}-\mathrm{MS}$, Journal of Instrumental Analysis.

Tahsin, T., Wansi, J.D., Al-Groshi, A., Evans, A.R., Nahar, L., Martin, C., et al., 2017, Cytotoxic properties of the stem bark of Citrus reticulata Blanco (Rutaceae), Phytotherapy Research, 31(8), 1215-1219.

Tumbas, V.T., Cetkovic, G.S., Dillass, S.M., Brunet, J.M.C., Vulic, J.J., Knez, Z. and Skerget, M., 2010, Antioxidant activity of mandarin (Citrus reticulata) peel, Acta periodica technologica, APTEFF, 41, 195-203.

Wen, S.S., Sun, L., An, R., Zhang, W., Xiang, L., et al., 2019, Combination of Citrus reticulate peel and black tea inhibits migration and invasion of 
Indonesian Journal of Cancer Chemoprevention, June 2020

ISSN: 2088-0197

e-ISSN: 2355-8989

liver cancer via PI3K/AKT and MMPs signaling pathway, Molecular Biology Reports, 47(1),507519.

World Health Organization, (2013), International Agency Research for Research on Cancer.
Wu, S.W., Cho, E., Feskanich, D., Li, W.Q., Qi, S., Han, J. and Qureshi, A.A., 2015, Citrus consumption and risk of basal cell carcinoma and squamous cell carcinoma of the skin, Carcinogenesis, 36(10), 1162-1168. 